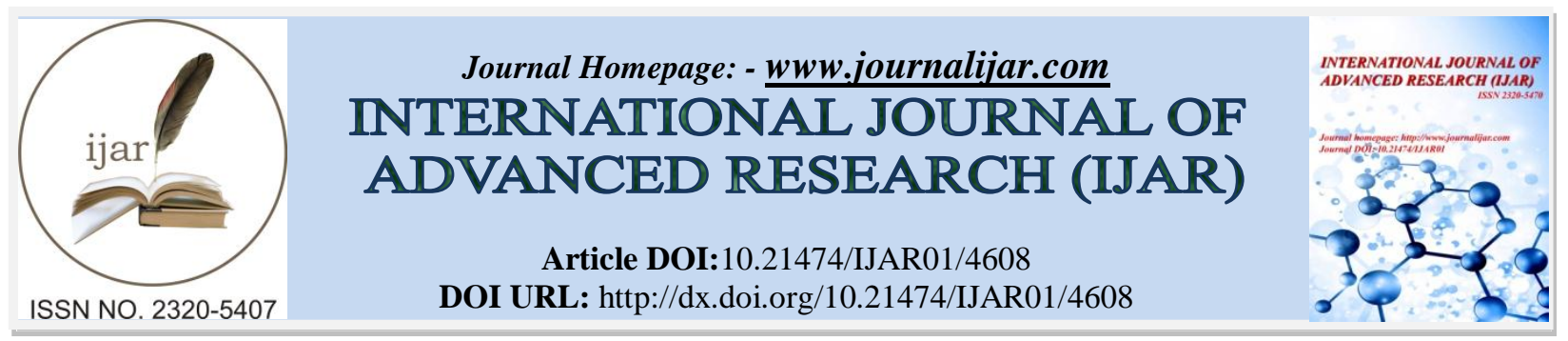

RESEARCH ARTICLE

\title{
EFFECT OF ENTREPRENEURSHIP ORIENTATION, LEADERSHIP SUCCESSION ON PERFORMANCE AND SUSTAINABILITY OF FAMILY BUSINESS WITH DELIBERATE PRACTICE AS MODERATOR VARIABLE: A CONCEPTUAL MODEL.
}

\author{
Daniel Kurniawan, S. T. M. A. M. M. ${ }^{1}$, Prof. Dr. Arsono Laksmana SE. Ak. CA. CPA ${ }^{1}$ and Prof. Dr. \\ Bambang Tjahjadi, M. B. A. Ak. CPM. CMA. CA ${ }^{2}$. \\ 1. Postgraduate School, Widya Mandala Catholic University. \\ 2. Faculty of Business and Economics, Airlangga University.
}

\section{Manuscript Info}

\section{Manuscript History}

Received: 25 April 2017

Final Accepted: 27 May 2017

Published: June 2017

Key words: -

entrepreneurship orientation, leadership succession, deliberate practice, family business performance, family business sustainability.

\section{Abstract}

Keeping the family business works through the changes of era is not an easy task. The proof that many family businesses that were once successful but has been ruined when it is run by the next generation. This is the reason why the family business continuity becomes an area of concern to various family business experts over the past decades. Factors that may affect the Family Business Sustainability used in this research includes Entrepreneurship Orientation, Leadership Succession and Family Business Performance. However, there is not much studies about the concept of Deliberate Practice in the area of family business, whereas it is very important to be monitored if the family wants to continue the business from generation to generation. Therefore, this study aims to produce a model that can be used to measure the continuity of family business. It is hoped that with this research, family businessmen can maintain their business by measuring the sustainability of their business by using this model.

Copy Right, IJAR, 2017,. All rights reserved.

\section{Introduction: -}

Referring to the World Competitiveness Report published by Lausanne Management Center, $80 \%$ of businesses in the world are family businesses. In the United States, family business contributes up to half of the GDP value and provide half of all employment across the United States. In Germany, family firms account for 66\% of GDP and $75 \%$ of employment providers.

It was found that $40 \%$ of the top 500 companies in the world are family companies (Lee and $\mathrm{Li}, 2009$ ). In developing countries, almost all companies are family enterprises. Moreover, in Asia, which is very closely related to association of values. In India, $70 \%$ of the 250 largest companies are family companies. Particularly in Southeast Asia where family companies are the largest contributors to GDP in the country.

However apparently, many tragic examples in which family business have to be ruined when the next generation fails to continue the baton. Whereas the majority of business in the world is a family business. In the context of Southeast Asia, researchers take the tragic example of a large family company that fails to stay sustain. Today, almost all Southeast Asian countries are familiar with Yeo Hiap Seng (YHS) products. The company is known as a manufacturer of beverages and canned food. YHS is a 100-years old company that works in area of food 
manufacturing. The company was originally a family company that has been changed into an ordinary business company. Founded in 1901 by Yeo KengLian in Zhang Zhou, Fujian, China. The eldest son of the family, Yeo Thian In also jump into the business that his father pioneered. With the control and directed by his father, Yeo Thian In works to raise the business. The father and son's hard work paid off because within a short time YHS products flooded Zhang Zhou. Unfortunately, fortune did not last long, in 1940 the political conditions of China became unstable. This makes Yeo Thian In with 7 brothers made a very hard decision to move to Singapore.

In this country, the Yeo brothers started everything from nothing. Thanks to the ongoing work and innovation of the Yeo brothers, YHS has grown back into a large company in Singapore. Not content to play in one country, YHS expanded to other countries such as Malaysia, Hong Kong, and even Europe. The 1960s to the 1980s became the glorious period of YHS.

The fall of the family business started to happen when the third generation of Yeo's family began to take over in 1990. Seven families who owned YHS shares grew bigger and the intrigue and politics between families grew higher as well. In just 5 years, YHS is finally out of the hands of Yeo's family. Hard work for almost a century, lost within 5 years. A tragic ending of a once-glorious family company.

Pojasek (2007) said the family company that is able to remain exist and sustainable as a living company is a visionary family company. This is very interesting because considering that in a family company, sustainability is a difficult thing to achieve (Lee and $\mathrm{Li}, 2009$ ). Furthermore, Lee and $\mathrm{Li}$ (2009) elaborated that a family business needs to think about sustainability from the start because it is especially vulnerable to the family business that was established by the first generation to be lost in the second or third generation.

Business sustainability measurements are evolving over time. Several business sustainability measurement methodologies are introduced by experts to achieve sustainability and continuously growing from theories to theories. Elkington (1994) says that business sustainability is a company's ability to achieve business goals and increase long-term value for shareholders by integrated economy, social and environment into its business strategy. With this, it can be concluded that sustainability of a company depends not only on internal factors of the company, but also on external factors.

Seeing the many challenges faced by home business in Indonesia, this research is conducted to produce a model to know the factors that can affect the sustainability of family business and how significant the effect given. This paper will assess different literature in order to elaborate the factor that can affect the sustainability of family business. Whereas, this paper also aim to seek the indicator from various factors that affect sustainability of family business. According to literature studies and previous research, there are 4 variables that can affect the sustainability of a family business that is 1) Entrepreneurship Orientation, 2) Leadership Succession, 3) Family Business Performance 4) Deliberate Practice which is rarely discussed in previous studies. In addition, this study also has a hypothesis if the factors no 1 and 2 also have an influence on Business Family Performance which is a factor number 3. As for factor 4 which is Deliberate Practice is estimated to have an impact on the impact of Family Business Performance on Family Business Sustainability. For more details, there are in the picture of the research model below: 


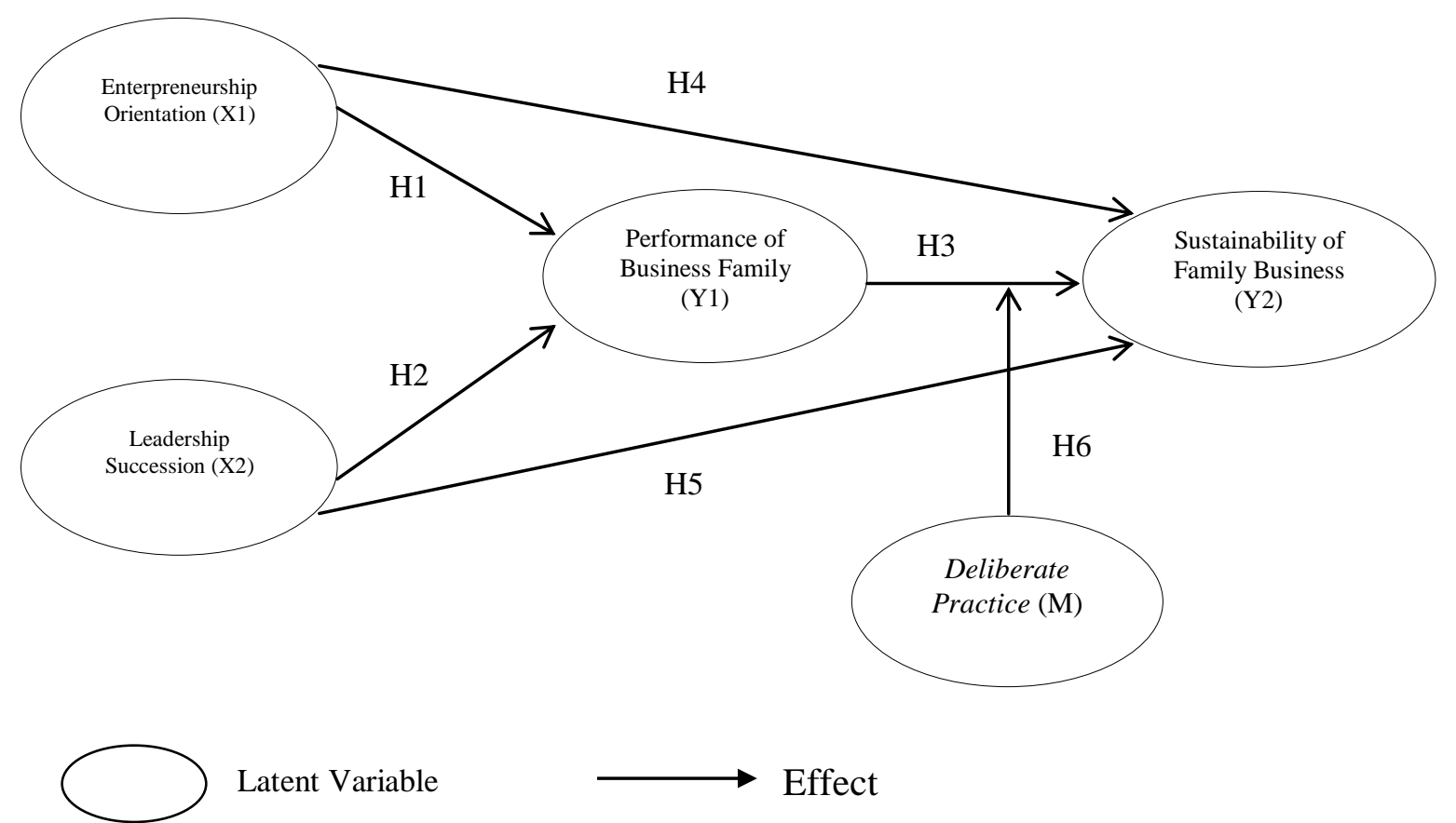

Figure 1: - Design Research Model

\section{Literature Review: - \\ Grand Theory:-}

Grand theories that are used to observe the phenomenon of family sustainability are structuralize theory, Reconstructionist, contingency, and entrepreneurial theory.

Structuralize theory emphasizes that the profitability potential of an enterprise is due to the performance-actionstructure paradigm, which can be seen from the cause-effect flow from the market structure to action and performance. The market structure created by supply and demand conditions that form a sell and buy action that ultimately determines the final performance (Bain, 1956).

Reconstructionist Theory emphasizes more on strategy, on the other hand built on endogenous growth theory (from within). Schumpeter says that the forces that change the economic structure and the industrial landscape can come from within the system and innovation can occur endogenously whose primary source is the creative entrepreneur. However, Schumpeterian innovation is still unknown to the work process, because innovation is a product of the brilliance of the entrepreneurs and cannot be systematically reproduced (Schumpeter, 1975).

Contingency theory says that organization is an open system (Donaldson, 2001). As a consequence, the organization will always be influenced by the surrounding environment. This theory believes that the design of organizational structure will be more effective when the structure is fit with all possibilities. Another opinion expressed by Hambrick (1983) which states that the theory of contingency is a theory that involves the process of identifying and matching the organization's situation with the context situation. Since 1960, much research has been done using contingency theory as its main framework. From organizational research to strategic management (Volberda et al., 2010).

As for the theory of entrepreneurship, Leibenstein (1979) describes the development of this theory which include:

1) Classic Neo Theory. This theory views the company as a technological term, in which management (individuals) only knows the cost and acceptance of the company and simply performs a mathematical calculation to determine the optimal value of the decision variable.

2) Kirzerian Entrepreneurship. Kirzer's theory highlights the performance of man, his tenacity, his seriousness, his sincerity of self in the enterprise, so the advancement of a business depends on the effort and tenacity of the entrepreneur. 
3) Theory of Sociological Entrepreneurship. This theory is more about the origins of culture and social values in a society, which will impact on its ability to respond to business opportunities and cultivate business.

4) Theory of Psychological entrepreneurship. This theory is more emphasis on the individual motives behind him for entrepreneurship, if since childhood implanted for achievement, then more likely an individual is more courageous in responding to business opportunities obtained.

5) Theory of Behavioral Entrepreneurship. A theory that emphasizes that an entrepreneur must have the skills in organizing a business, managing finances and related matters, building a network, and marketing a product, it takes a sociable and sociable person to promote a business.

In addition, there is a new combination of understanding in entrepreneurship theory developed by Bull and Willard (1993) namely, that entrepreneurship will occur with maximum in conditions:

1. Task-related motivation: some vision or sense of social value embedded in the basic task itself that motivates the initiator to act.

2. Expertise: ability to present know-how plus confidence to be able to obtain know-how needed in the future.

3. Expectation of gain for self: economic and / or psychic benefits.

4. A supportive environment: conditions that either provide comfort and support to the new endeavor, or that reduce discomfort from a previous endeavor.

If structuralism theory says that business sustainability is related to the external conditions of the company, on the contrary, entrepreneurial theory is more to say that business sustainability is related to Internal conditions (reconstructionist theory). Therefore, a contingency theory approach is needed, as a solution to the theoretical gap. Contingency theory can be used to analyze design and management systems to provide information that companies can use for various purposes and to face competition (Otley, 1990).

Apart from the theoretical gap that can be closed by contingency theory, also related problems empirical gap which finally also allegedly able to solve the problem of family business problems. Many of the research models in the formulation and implementation of management strategies are based on contingency theory. With empirical evidence the relationship of contingency control, a universal view (that there is one particular way to deal with one particular problem) is allegedly not applicable to the family business. Therefore, a "special-condition" model approach to this challenge is needed.

From some of the existing empirical gaps, especially the phenomenon of sustainability of family businesses in Indonesia, according to Susanto (2007) the most important is the problem of succession, because when there is no planned succession, then as good as any performance of a family business, will not be able to keep Sustainability. Some gaps that occur in leadership successions that are closely related to the sustainability of family businesses are:

\section{Planned Succession: -}

Succession planning focusing on the candidates who will be in key positions has been prepared and the Accelerated Development Program is then given to provide insights into key issues and to improve the experience and policy of thinking.

\section{Informal Succession: -}

Succession planning leads more to giving experience by giving a position under the number one person and directly receiving the person's instructions and instructions.

\section{Unplanned Succession: -}

The transition of the top leadership to the successor is based on the owner's decision by prioritizing personal considerations.

That in order to create family business sustainability, the most important thing is the planned succession, meaning intergenerational succession has been designed in such a long way by the founding generation that the next generation is ready and mature before working to run the family business.

Orientation of Entrepreneurship (Entrepreneurship Orientation): -

The entrepreneurial orientation is defined as a set of processes that companies use to stimulate innovation, risk taking, and active activities. Therefore, entrepreneurship orientation is more appropriate when measured using 3 
instruments developed by Covin and Slevin (1988) whose explanations of definitions and measurements are as follows.

\author{
Proactiveness: the company's ability to always take initiative in pursuing market opportunities, consists of 3 \\ measuring instruments, namely: - \\ $>$ Initiative to move forward. \\ $>$ Anticipate the actions of competitors. \\ $>$ Have the speed to offer something new in the market.
}

Innovativeness: the tendency of companies to support the occurrence of new ideas, unique and creative process, consists of 3 measuring instruments, namely:

$>$ The company provides support for product research and development.

$>$ The company is trying to deviate from the status quo.

$>$ The company provides support for creative new ideas.

Risk-taking: the willingness of a company to commit to using the full available resources for a project, although the probability and cost of failure is very high, consisting of 4 items of measuring instruments:

$>$ The company is fully allocating resources to create new things.

$>$ Companies dare to spend working capital loan to make new things.

$>$ Companies often explore activities that have never been done.

$>$ Companies are increasingly aggressive in making decisions.

\title{
Leadership Succession: -
}

The definition of a leadership succession according to Higginson (2010) is "ensuring that the next generation is well protected to assume the leadership / ownership's role within the firm." From this definition, the succession process not only talks about the shift of leadership batons, but also the certainty that the next generation is ready to play a role in the family company.

Leadership succession is more appropriate when measured by the instruments developed by Higginson (2010), where factors affecting family business succession are grouped into four dimensions:

Connectedness: "extensive social, supporting, and inter-firm networks of relationships of varying degrees of closeness as important providers of valuable knowledge resources for their firms". Consists of 3 measuring instruments, namely:

* A lot of social networks (social networks, such as the surrounding community, co-workers, etc.)

* Many support networks (supporting networks, such as various related industry associations) are owned by a company.

* Numerous inter-firm network (a cross-enterprise network, such as banking, suppliers, etc.) owned by a company.

Cognition: refers to the capacity of people to engage in dialogue ideas in a problem-solving context in order to arrive at a logical, workable solution. Consists of 2 measuring instruments, namely:

a) The more frequency in which parents invite their children to talk about the conditions experienced by the company.

b) The more frequency in which the child engages in a formal job and his position is considered an ordinary employee.

Reflection: as the capacity to accommodate and cope with ambiguity, uncertainty, and a wide range of people and situations ". Consists of 2 items, namely:

a) The more parents give their children the opportunity to run an important area of business so that they get more responsibility.

b) The more often parents invite their children to discuss to solve a problem that is being faced in business.

Affection: "emotional processes, which are powerful determinants of behavior, become embedded in family business by way of the relationships between family members". Consists of 2 items, namely:

a) The less conflict / friction between family members. 
b) The stronger the norm (the unwritten rule) in a family in which every member of the family can also obey those rules really well.

\section{Deliberate Practice: -}

According to Sonnentag and Kleine (2000), deliberate practice is the process of learning and practicing continuously in the right way. Deliberate practice is how everyone can master fundamental skills correctly, so that it can form a framework and big picture of it, and form and train someone to be a champion and superior in the field. Finally, can give totality when doing that, because already have the right basics.

Deliberate practice is more accurate when measured by instruments developed by Sonnentag and Kleine (2000), namely:

1) The first aspect, mental stimulation: a state in which every member of an organization must be able to continually stimulate itself to have a never-satisfied mentality of the existing work. Consists of several items, namely:

a) The more motivated the family members to make things better in the company, the higher the degree of mental stimulation.

b) The more members of the family feel that the work is less than the maximum, so it can be improved, the higher the degree of mental stimulation.

2) The second aspect, asking for feedback: the circumstances in which every member of the organization always asks for feedback on the work that has been done, it is for future improvement. Consists of: The more frequently requested to request feedback in the form of suggestions, the higher the degree of asking for feedback.

3) The third aspect, preparation: the circumstances in which every member of the organization always prepares everything well before starting an activity, especially projects that are directly related to the customer. Consisting of: The more prepared a person in a regular meeting presentation, both from the content, self-view, and support tools, the higher degree of preparation.

4) The fourth aspect, consulting colleagues: the circumstances in which every member of the organization actively consults with co-workers, especially with seniors, to request direction so that work is more effective in the future. Consists of several items, namely:

a. The more often the direction of the way and attitude of work from senior to junior, the higher the degree of consulting colleagues.

b. The more often the direction of strategy forward from senior to junior, the higher degree of consulting colleagues.

5) The fifth aspect, assessment: the circumstances in which each member of the organization is willing to take the time to evaluate himself, and ask for evaluation from the management to improve performance. Consists of: The more often the process of evaluating the way and attitude of work from superiors to subordinates, the higher the degree of assessment.

\section{Family Business Performance: -}

Measurement of business performance has become a lengthy discussion. According to Hofer (1983) business performance can be measured by financial indicators such as sales growth, profitability, return on investment, return on sale, and return on equity (in Venkatraman and Ramanujam, 1986). However, this variable must be measured holistically and not only in financial terms only. Therefore, family business performance is more appropriate if measured holistically based on the instruments developed by Matic (2012), namely:

1. First, sales growth: the rate of increase in market size, generally expressed as a percentage per year. Consists of several items of measuring instruments, among them are:

a) Growth of company's sales based on nominal, the higher the difference of gross year turnover compared to previous year, hence the higher sales growth.

b) The company's sales growth is based on the number of products, the higher the total units sold in the current year than the previous year, the higher the sales growth.

c) The company's sales growth is based on the number of subscribers, the more number of new customers in the current year than the previous year, the higher the sales growth.

2. Second, the organization reputation: stakeholder evaluation of the company's reputation, based on the stakeholder's experience of the company concerned. Consists of several measuring instruments, among them are: 
a) External reputation associated with the public perception of how the quality, feelings and corporate image in the community.

b) The internal reputation associated with employee perceptions is about how the company feels and feels internally.

3. Third, employee satisfaction: the emotional state, whether pleasant or unpleasant with which the workers perceive their work. Consists of one measuring instrument, among which are:

a) Turn-over employees, namely the higher the number of employee turnover in a company, the more reduced employee job satisfaction in the company.

b) Does the company pay attention to the physical health of employees?

c) Does the company pay attention to employee emotional health?

d) Does the company give rewards / punishment according to the performance of employees?

\section{Business Family Sustainability:-}

According to Pojasek (2007), a family company that is able to exist and sustain as a living company is a visionary family company. This model company does not overwhelm the maximization of shareholder wealth, although it is acknowledged that profitability is a must as a company's means to exist. However, profit is not everything, so even with the concept of business is not just an economic activity, but tends to prioritize the interests of stakeholders, including employees. The sustainability of a family business is defined as the degree to which a family company is able to exist and sustain as a living company, to be a visionary family company. Therefore, family business sustainability is more appropriate if measured based on the instruments developed by Pojasek (2007), namely:

4. First, thinking system: the efforts of family companies to make the system work becomes more systematic and measurable, especially the involvement of professional employees who sit in the management level. Consists of several measuring instruments, among them are:

a) The existence of standard operational procedures of the company is consistently maintain; The more standardized work processes and neatly written into the SOP (standard operational procedures), the higher the degree of "system thinking".

b) The involvement of professional employees within the company. The more professional employee involvement in the company, the more objective is the direction the company will take (the higher the degree of system thinking), than if there are too many families involved, where sometimes the family quarrel causes the company to be ruined.

5. Second, continuous improvement: the effort of family company to continuously improvement, in terms of organization, and production. Consists of several measuring instruments, among them are:

a) The existence of regular organizational changes within the company; The more often the change in the composition of the function and the number of teams in the organization, then the more dynamic indicated a company, or in other words a continuous improvement (continuous improvement).

b) Changes in production methods to be more efficient in the company; The more production processes that have been replaced in such a way as to be more efficient, the more progressive development occurs (continuous improvement).

6. Third, information \& knowledge: the family enterprise effort to learn about new things, whether related to core business or not directly related. Consists of several measuring instruments, among them are:

a) Update for the latest trend information about the market; The more frequent regular meetings in which it also discusses the latest market trend information, the higher degree of information \& knowledge that exists within the family enterprise.

b) Update for information on competitors; The more frequent regular meetings in which it also discusses the information of competitors, the higher degree of information \& knowledge in the family enterprise. 


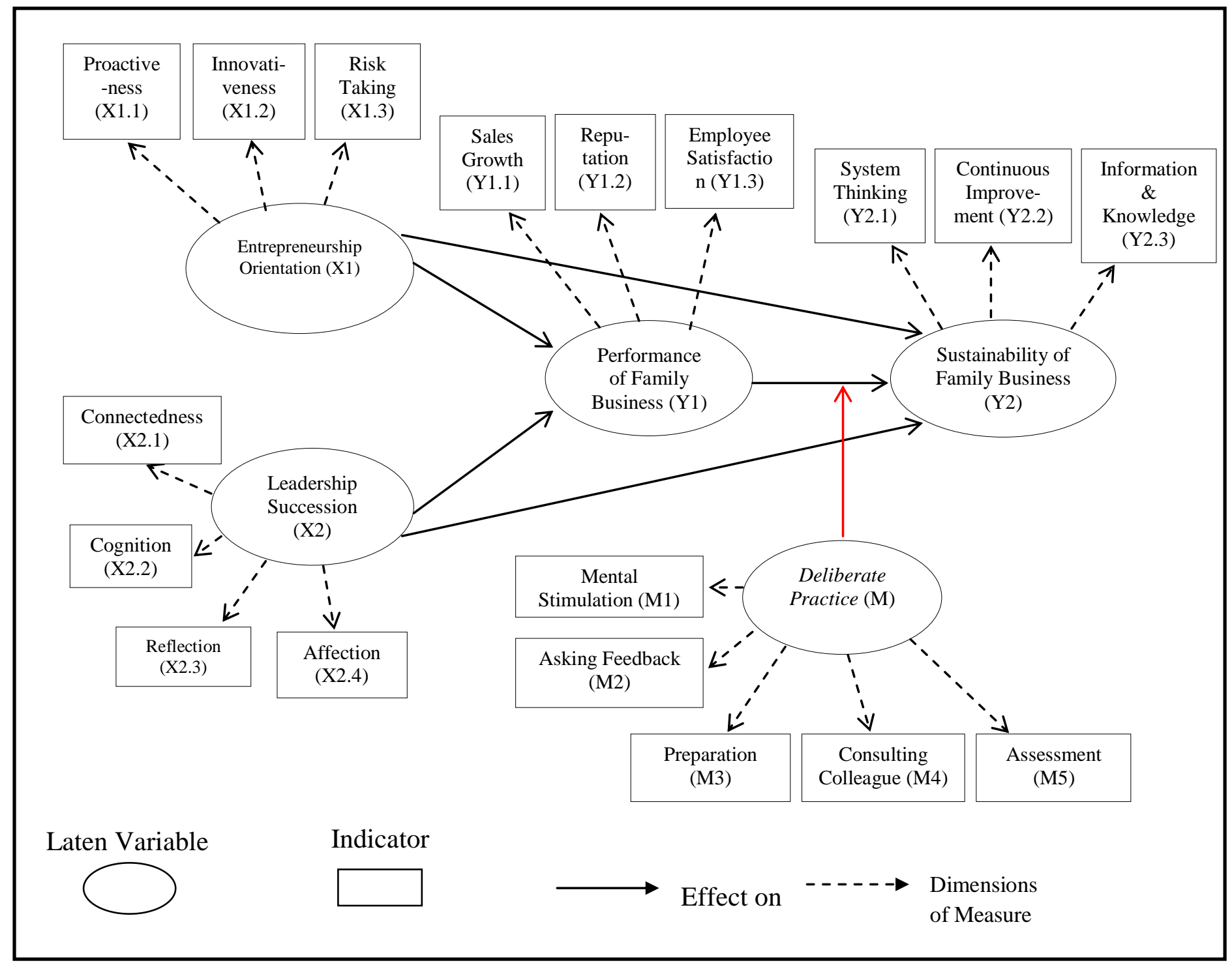

Figure 2: - Total Research Model Design to Find the Sustainability of Family Business

\section{Conclusion:-}

From the literature study above, it can be concluded that the overall sustainability of family business can be influenced by four factors: Entrepreneurship Orientation, Leadership Succession, Deliberate Practice and Family Business Performance. However, the Entrepreneurship Orientation and Leadership Succession can also affect the Family Business Performance. While Deliberate Practice has an influence on the impact of Family Business Performance on Family Business Sustainability. The model for measuring Business Family Sustainability along with the variables and indicators is shown on figures 2 above. 


\section{Bibliography:-}

1. Bain, J. S. (1956). Barriers to New Competition: Their Character and Consequences in Manufacturing Industries. Cambridge: Harvard University Press.

2. Bull, I., \& Willard, G. E. (1993). Towards a theory of entrepreneurship. Journal of business venturing, 8(3), 183-195.

3. Covin, J. G., \&Slevin, D. P. (1990). New venture strategic posture, structure, and performance: An industry life cycle analysis. Journal of business venturing, 5(2), 123-135.

4. Donaldson, L. (2001). The Contingency Theory of Organizations. Thousand Oaks: Sage Publication.

5. Elkington, J. (1994). Towards The Sustainable Corporation: Win-Win-Win Business Strategies for Sustainable Development. California management review, 36(2), 90-100.

6. Hambrick, D. C. (1983). Some tests of the effectiveness and functional attributes of Miles and Snow's strategic types. Acad. Management J. 26(1) 5-26

7. Higginson, Nancy (2010). Preparing the next generation for the family business: relational factors and knowledge transfer in mother-to-daughter succession. Journal of Management and Marketing Research.

8. Leibenstein, H. (1979). A branch of economics is missing: micro-micro theory. Journal of Economic Literature, 17(2), 477-502.

9. Matić, I. (2012). Measuring the effects of learning on business performances: Proposed performance measurement model. The Journal of American Academy of Business, Cambridge, 18(1), 278-284.

10. Otley, D. (1994). Management control in contemporary organizations: towards a wider framework. Management accounting research, 5(3), 289-299.

11. Pojasek, R. B. (2007). A Framework for Business Sustainability. Environmental Quality Management, 17(2), 81-88.

12. Schumpeter, J. (1975). The Future of Private Enterprise in The Face of Modern Socialistic Tendencies. History of Political Economy, 7(3), 294-298.

13. Sonnentag, S., \& Kleine, B. M. (2000). Deliberate Practice at Work: A Study with Insurance Agents. Journal of Occupational and Organizational Psychology,73(1), 87-102.

14. Susanto, A.B. (2007). The Jakarta Consulting Group on Family Business. Jakarta: The Jakarta Consulting Group.

15. Venkatraman, N.\&Ramanujam, V. (1986). Measurement of Business Performance in Strategy Research: A Comparison of Approaches. The Academy of Management Review, 11(4), 801-814

16. Volberda, H. W., N. J. Foss, M. A. Lyles. (2010). Absorbing the concept of absorptive capacity: How to realize its potential in the organization field. Organization Science. 21(4) 931-951. 